\title{
Reseña de "Los trajines callejeros. Memoria y vida cotidiana" (Eduardo Kingman Garcés y Blanca Muratorio, 2014)
}

\author{
María Ángela Cifuentes Guerra- Universität Düsseldorf ${ }^{1}$
}

DOI:http://dx.doi.org/10.5565/rev/periferia.593

\section{Resumen}

Fruto de un trabajo conjunto, Eduardo Kingman Garcés y Blanca Muratorio exploran a lo largo de los diferentes textos que comprenden este libro el significado cultural de los trajines callejeros y otras formas de entender y estudiar las culturas urbanas. El relato, la imagen visual y el objeto se presentan como sus recursos centrales para un análisis compartido entre la historia y la antropología. Quito en su primera modernidad, entre los siglos XIX y XX, es el objeto de gran parte de sus análisis aquí expuestos.

Palabras clave: trajines, intercambio, disputas, memoria, campo, urbano, vida cotidiana.

\begin{abstract}
As result of their joint work, Eduardo Kingman Garcés and Blanca Muratorio, throughout the different texts of this book, are exploring the cultural meanings of the streets bustles and other forms to understand and study urban cultures. Narration, visual image and objects are the main resources for a joint analysis among of history and anthropology. Quito in its first modernity, between the 19th and 20th century, is the subject of an important part of their studies.
\end{abstract}

Keywords: bustles, exchange, dispute, memory, land, urban, every-day life.

\section{La vida urbana}

¿Cómo construir historias de la ciudad en base a sus intercambios simbólicos, a los usos y prácticas que generan a la vez espacios en disputa? ¿Con qué recursos se puede levantar la memoria de la vida cotidiana para seguir el tejido de las relaciones sociales y culturales en espacios de circulación e intercambios?

\footnotetext{
${ }^{1}$ Enviar correspondencia a: María Ángela Cifuentes Guerra: maria.angela.cifuentes@gmail.com
} 
Autor/es, título, perifèria $x(y)$, mes 2016

revistes.uab.cat/periferia

En sus ensayos recogidos en el libro Los trajines callejeros. Memoria y vida cotidiana. Quito, siglos XIX-XX (Quito, 2014), Eduardo Kingman Garcés y Blanca Muratorio indagan y analizan de una manera apasionante y sensible la vida urbana a partir de trajines callejeros, de espacios de intercambio simbólico en Quito durante la experimentación de la primera modernidad.

Si pensamos en el acto de trajinar, podemos suponer en primera instancia el acto de andar, de trasladarnos de un lado a otro estableciendo intercambios ${ }^{2}$. Ello implica el hecho de realizar contactos, de generar asociaciones y disociaciones entre personas del mismo grupo con aquellos "otros" diferentes. Refiriéndose a los trajines callejeros tratados en el libro, Kingman explica que éstos "conciernen a formas de circulación paralelas, caracterizadas por flujos constantes entre la ciudad y el campo, la conjugación de economías formales y no formales y una relativa autonomía con respecto a la acción del Estado" (2014:9), que podrían relacionárselos con aquellos 'contratos' que se fundan en el movimiento del andar, los cuales Michel de Certeau define como relaciones entre posiciones diferenciadas (1996:110). Algo similar sucede en el ejercicio de los trajinantes, quienes en su andar van tejiendo redes de intercambio, pero a la vez van moviéndose entre lugares y tiempos, creando así espacios para negociar, disputar o resignificar.

El sentido de los trajines callejeros abordados en los análisis que componen este libro nos lleva a imaginar prácticas que de alguna manera unían la ciudad con el campo en épocas cuando las élites trataban de adoptar formas neoclásicas de portar signos del progreso. El comercio popular y los antiguos oficios contrastaban con formas y políticas modernizadoras enmarcadas en el ornato, el salubrismo y la planificación; se hallaban en relaciones de disputa con el tiempo para sortearse en medio de transformaciones, con el peligro que ello implica para su desaparición. Es el caso por ejemplo de poblaciones flotantes provenientes de sectores aledaños a la ciudad o de barrios de indios que, como señala Kingman, se ocupaban de oficios dentro del comercio, los servicios, o la construcción (2014: 34). Estaban también

\footnotetext{
${ }^{2}$ La Real Academia Española define la palabra trajinar como "acarrear o llevar géneros de un lugar a otro" (cfr: www.rae.es).
} 
Autor/es, título, perifèria $x(y)$, mes 2016

revistes.uab.cat/periferia

las cajoneras o buhoneras, a quienes Muratorio dedica un capítulo, o como el gremio de los albañiles en el estudio tan cercano y personal que entrega Kingman.

Pero, ¿hasta qué punto resistían y a la vez iban transformándose estos oficios y sus portadores en la marcha del tiempo al estar expuestos a cambios físicos de la ciudad, como también a cambios de órdenes, de usos, de formas de producción y consumo dentro del comercio global? ¿Cuáles son ahora sus luchas y estrategias para sobrevivir $y$, al mismo tiempo, cómo son sus transformaciones? ¿Son o no conscientes de ellas?

Muratorio y Kingman hacen de la memoria el recurso, el instrumento para el conocimiento y el entendimiento de vidas muchas veces existentes a la sombra de las historias oficiales. Hacen perceptible lo que parece imperceptible en el trajinar de la cotidianidad. Su método está en la activación de otras memorias posibles desde la Historia y la Antropología, Ilamándolas "memorias paralelas" (2014: 11), es decir, aquellas que emergen de las preguntas, de las indagaciones que hacemos a los silencios en lo existente. Porque si se habla de la memoria, se habla también del olvido y de formas de mantenerse entre ambos estadios (relatos, recuerdos, objetos como depositarios de memoria, juegos de intereses, convenciones, valores a mantener y a reproducir...); Kingman señala que "[n]ecesitamos saber qué es lo que hace significativos a determinados hechos, ya sean cuadros de milagros, pinturas de Tigua, relatos de la sociedad de una época, y hacerlo desde un espacio de reflexión y de disputa de significados". (2014: 12)

Allí están las cajoneras, personajes que forman parte de la vida del centro histórico de Quito, cuyo oficio va desapareciendo o siendo sustituido por lugares de expendio de objetos producidos a gran escala made in China en shopping malls o grandes almacenes. Están expuestas sus batallas por hacer de la calle el espacio de práctica de su oficio en medio de disputas y exclusión desde el siglo XIX hasta la actualidad. La calle se convierte así en un espacio de tensión y estrategias en tanto representa el afuera visible y perceptible, pues es allí donde queda al descubierto lo que se mira y se escucha (Delgado, 2007: 30), lo que puede incomodar a los sentidos. En tiempos de una modernidad ordenadora en el aseo, el ornato y el salubrismo, las cajoneras representaban precisamente lo que afeaba y ensuciaba el espacio público 
Autor/es, título, perifèria $x(y)$, mes 2016

revistes.uab.cat/periferia

(Kingman y Muratorio, 2014: 214). Muratorio levanta las voces de los sectores sociales en disputa -la élite y el pueblo-, exponiendo los significados en confrontación pues la élite, en nombre del ornato, la limpieza y el orden, defendía lo que concebía como 'bien público', en tanto las cajoneras defendían lo que para ellas era un derecho simbólico como "legítima compensación de los servicios prestados por (nuestros) esposos é hijos, para el sostenimiento del orden público, y de la sangre derramada en los campos de batalla, para la defensa de las instituciones republicanas" (Muratorio, 2014: 123). ¿Acaso esas mismas batallas no están todavía presentes en las ciudades que habitamos y que crecen entre diferentes tiempos y realidades?

El ensayo de Eduardo KingmanMateriales de la memoria. El gremio de albañiles de Quito, lleva a reflexionar sobre la labor del historiador recurriendo a la memoria social como fuente y como metodología. Resulta sumamente apasionante en su tratamiento el cruce de tiempos entre la perspectiva del historiador, quien procura reconstruir el pasado a través de los fragmentos que ofrecen los recuerdos, y la perspectiva del narrador o informante, que habla del pasado preguntándose en el presente sobre su existencia y condición a raíz de lo ya vivido. La voz hace las veces de recurso en ese cruce de pasado y presente, como si el acto de recordar y narrar fuera creando espacios de memoria. De allí la importancia de los cuestionamientos de Kingman para ir a través del relato oral más allá de la labor gremial o sindical del informante y entender aspectos de la vida cotidiana, de las políticas de representación y de producción de significados. Están por ejemplo valores como el prestigio y el respeto intermediados por cuestiones de clase, oficio o apellidos en sociedades aún gobernadas por las formas y relaciones tradicionales de un sistema hacendario.

En los trajines callejeros se daban también las contradicciones de la modernidad entre lo que se quería representar en la ciudad y lo que las realidades encerraban en sí. Sería en las prácticas donde estos cruces de sentido y representación se hacían perceptibles, como Kingman expone en el capítulo Oficios y trajines callejeros. Por un lado existía una intención mimética de adoptar la modernidad expuesta en la forma; así por ejemplo en la arquitectura, la moda, el ordenamiento 
Autor/es, título, perifèria $x(y)$, mes 2016

revistes.uab.cat/periferia

urbano. Por otro lado, se daba una modernidad biopolítica de vigilancia y gobierno de sujetos (2014: 57). En ritos religiosos, nacionales, o de esparcimiento,las fronteras entre élite y sectores populares parecían entrecruzarse o diluirse por momentos dentro de un imaginario de una cultura en común, "concebida en términos ideales", escribe Kingman, "como 'alma' o 'espíritu de la nación', capaz de integrar a ciudadanos y no ciudadanos (hombres y mujeres, nobles y esclavos)" (2014: 53). Esta cultura en común, sin embargo, respondía a un proyecto conservador de cultura nacional, con bases más bien culturales, expuesto en prácticas de trastocamiento de la vida cotidiana.

Estaban asimismo ritos híbridos que creaban espacios de cruces de poder y contrapoder al igual que momentos en los que estas fronteras parecían difuminarse y a la vez resignificarse. Es el caso del Carnaval. La broma, la burla, la risa que en principio son liberadoras, podían ser al mismo tiempo recursos para la resignificación de las fronteras frente al "otro". Y al mismo tiempo se daban espacios de permisibilidad para quienes en la cotidianidad estaban al margen de los privilegios de la élite. En la fiesta del Carnaval, manifestada en el juego de agredir con agua, huevos, o lodo, se atravesaba la frontera de poder, aunque fuera en el instante del disfrute.

\section{Imágenes y narraciones}

Al igual que las narraciones, las imágenes visuales cumplen un gran rol en este libro. Las narraciones han contribuido a profundizar conceptos y entendimientos; las imágenes, por su lado, han sido fuentes esenciales para comprender formas simbólicas que dan significado a estados de vida y muerte, formas que crean presencias para sustituir ausencias, o formas de gratitud a través de puestas en escena de milagros recibidos.

- Es extraordinaria la manera cómo Blanca Muratorio entra en el mundo de las imágenes para extraer de ellas la riqueza mnemónica y simbólica en estadios de traspasos, como expone en el capítulo Historia y memorias sociales: un coleccionista de presencias y evocaciones populares. A partir de la colección de retratos de niños y niñas en posesión de Iván Cruz, Muratorio explora en el valor cultural de las memorias individuales y sociales que se encierran en estos 
Autor/es, título, perifèria $x(y)$, mes 2016

revistes.uab.cat/periferia

cuadros de finales del siglo XIX e inicios del XX. En ellos existe una constante: la relación de vida y muerte, o de ausencia y presencia, cumpliendo el retrato una función, no solo representacional, sino también terapéutica. El retrato cubre una ausencia al transformarse en una presencia simbólica. Tres tipos de imágenes son consideradas en este estudio:

- retratos conmemorativos póstumos de niños muertos que aparecen representados como vivos.

- cuadros de acción de gracias por milagros recibidos al ser rescatados niños del peligro de muerte.

- retratos de niñas poco antes de entrar a un convento religioso.

Los retratos post-mortem (realizados fotográficamente a manera de retratos funerarios o pictóricamente en estudios de pose y vestuario), así como aquellos de las jovencitas próximas a su vida conventual, guardan en común la separación del(la) retratado(a) del seno familiar; en el primer caso se trata de una muerte real mientras que en el otro está implícita una "muerte simbólica" en el traspaso de la niña que abandona la vida civil hacia una vida religiosa, de encierro y entrega absoluta a Dios. Los cuadros de acción de gracias representan lo opuesto en tanto celebran la vida tras vencer el peligro de la muerte. La imagen encierra un género híbrido al entrecruzarse una narración visual del milagro como acontecimiento en la vida de la víctima y de su familia con una narración textual por medio de descripciones escritas de los episodios, las que se hallan integradas en varias de las representaciones.

Cada uno de los trabajos que integran este libro son maravillosos aportes en el análisis histórico y antropológico a través del tratamiento de la memoria contenida en relatos, imágenes y objetos. Muestran la riqueza y el valor de estas fuentes y materiales para el conocimiento y el debate de fuerzas en disputa, del recuerdo como recurso para indagar sobre las diferentes realidades, así también sobre los diversostiempos y espacios que conforman las culturas urbanas. 
Autor/es, título, perifèria $x(y)$, mes 2016

revistes.uab.cat/periferia

\section{Bibliografía}

De Certeau, M. (1996). La invención de lo cotidiano, Vol. I.México, Universidad Iberoamericana: Instituto Tecnológico de Estudios Superiores de Occidente.

Delgado, M. (2007). Sociedades movedizas. Pasos hacia una antropología de las calles, Barcelona: Anagrama.

Kingman Garcés, E. y B. Muratorio (2014). Los trajines callejeros. Memoria y vida cotidiana. Quito, siglos XIX-XX, Quito: FLACSO-Sede Ecuador / Instituto Metropolitano de Patrimonio / Fundación Museos de la Ciudad. 